DOI: 10.20472/BMC.2018.007.002

JIRI KUTLAK

University of West Bohemia, Czech Republic

\title{
DIFFERENT GENERATIONS IN THE LABOR MARKET - IMPLICATIONS FOR THE WORKPLACE: THE CASE OF THE CZECH REPUBLIC
}

\begin{abstract}
:
The issue of generations, namely the focus on their characteristics and the current and future impact on business practices, is the key factor for business management due to the diversity of this generations. The paper on this issue aims to analyze the current and future trend of generation groups in the Czech Republic with respect to their characteristics and to the demography development on the Czech labor market. The paper theoretically defines issues of demographic development and generations (Baby Boomers, $X, Y, Z$ ), including their often different timing anchors and qualitative characteristics. Subsequently, on the basis of statistical data analysis, the labor market situation in the Czech Republic is characterized by a focus on individual generations. The paper also analyzes the population development of individual generations with the presentation of the 5 and 10-year forecasts. In the end, there are presented possible threats (change of generation groups, occupying higher positions, similarity of generations) or opportunities (unique diversity) that companies should take into account in their business practices. There are also three areas (evaluation, communication and mentoring) where the author presents the possible management of business processes and their limitation.
\end{abstract}

\section{Keywords:}

generation; generation groups; management; workforce; generation differences; demographic development

JEL Classification: M54, J11 


\section{Introduction}

The phenomenon of employment or unemployment is one of the central motives we encounter in analyzing or evaluating the performance of individual economies. The importance of this phenomenon confirms a number of comments in the media space, on the political scene or in the academic sphere, especially during the economic growth or conversely decrease, when employment and reciprocal unemployment reach border values (Cabla and Mala, 2017; Hedvicakova and Svobodova; 2017). Despite the fact that the labor force development in these economies is subject to many analyzes and predictions, it is often only a percentage estimate of future developments, which is focused, due to frequent changes in the global economic field, only on shorter periods of time (months, units of years). These are undoubtedly a very important component for many institutions headed by governments or central banks, however, when analyzing a wider timeframe, it is possible to meet the concept of generational groups or generations.

Generations cover a certain part of the population (by year of birth). For example, Jandourek (2007, p. 94) defines the generation as follows: "groupings of relatives of age groups who have undergone a socialization process in similar historical and cultural conditions." Different periods in which a given part of the population is formed have an undisputed influence both on individual enterprises and on an overall economy (Mannheim and Wolff; 1993). This impact is reflected in labor markets as a result of the basic economic understanding of the market as such. There is a supply of work (households / individuals) and a labor demand (businesses, companies, etc.) (Mach, 2001). The supply side is then logically formed by certain generational groups that, by their size and influence, directly affect the business and its processes.

As the term of the "generation group" suggests, it is a sociodemographic concept (Preston, 2001). It is therefore crucial to characterize necessary aspects of sociodemographic issues for the purposes of this paper. Specifically, this is the time-frame of individual generations, which differ not only between countries, but even among the authors themselves (Benson and Brown, 2011; Deloitte, 2015; Lyons and Kuron, 2013; Robinson, 2017). Another related term that characterizes the paper is a demographic development of the state, in this case the Czech Republic ("CZE"). The demography has an impact both on the number of representatives of each generation group and on their development over time. It is the development in time which determines the movement of the labor force in the economy. At the same time, the characteristics of individual generational groups, due to the size of their share of the labor market, influence the actions of companies. This fact becomes particularly important in the current situation, when according to the Ministry of Labor and Social Affairs (2017) ("MLSA"), the general unemployment rate (ILO methodology) in the first half of 2017, due to the drop in the number of unemployed by 48.8 thousand, declined from $4.1 \%$ to $3.2 \%$ (by 0.9 percentage points) year-on-year.

According to current data, the general unemployment rate is 2.4\% (Q4 2017), which is in absolute terms about 129 thousand unemployed. This is the lowest level of the 
unemployment since 1997 (CZSO, 2018). It can be assumed that while maintaining the current trend, at the end of spring, the CZE will become the first country in the European Union ("EU"), where there will be more jobs than job seekers. This is what keeps businesses busy with job-filling problems (Dufek, 2018).

The purpose of this paper is to quantitatively and qualitatively analyze the development of the workforce, focusing on issues of generations, their characteristics and impact on business practices in the Czech Republic. The article is structured as follows. In the first part, the concept of generation is theoretically defined and generational groups are characterized, including their annual anchor. In the next part, based on the obtained data and information, the resulting findings and suggestions for corporate practice are formulated. These are part of the evaluation and discussion chapter followed by the conclusion itself.

\section{Literature Review}

In the following subchapters, the areas of a demographic (population) development are theoretically defined. The term of generation is also defined. Based on the research, this term also includes the annual classification of individual generational groups and the more detailed characteristics of each generation.

\section{Generations and Demography}

The basic demographic term that is closely related to the next chapter, which theoretically defines each generation group, is the concept of generation. This term refers to a part of the population, a group of individuals who have similar views, attitudes, etc., based on the fact that they have socialized under same cultural, historical, economic and other conditions (Ardielli, 2016; Koschin, 2005). The generation is divided by age into economic (0-14 years, 15-64 years and 65+ years) or biological (0-14 years, 15-49 years and 50+ years) (Pavlik a Kalibova, 2005).

Demographic development of the population is most often captured using the so-called age pyramid / structure, which is a graphic representation of the age distribution of the population. The $x$-axis is divided into the right part (number of women) and the left part (number of men) when the y-axis forms the age group. Picture 1 depicts 4 basic types of pyramids and the representation of individual components ${ }^{1}$ in each of them. A progressive type is typical only for historical populations or ethnic minorities, but we are currently experiencing a stationary, stable and regressive type, the last two of which are typical of developed economies, such as the CZE (Koschin, 2005).

\footnotetext{
${ }^{1}$ Age of the individual components (generations) is expressed by biological age scales (Ardielli, 2016).
} 


\section{Picture (1): Types of Age Pyramids}

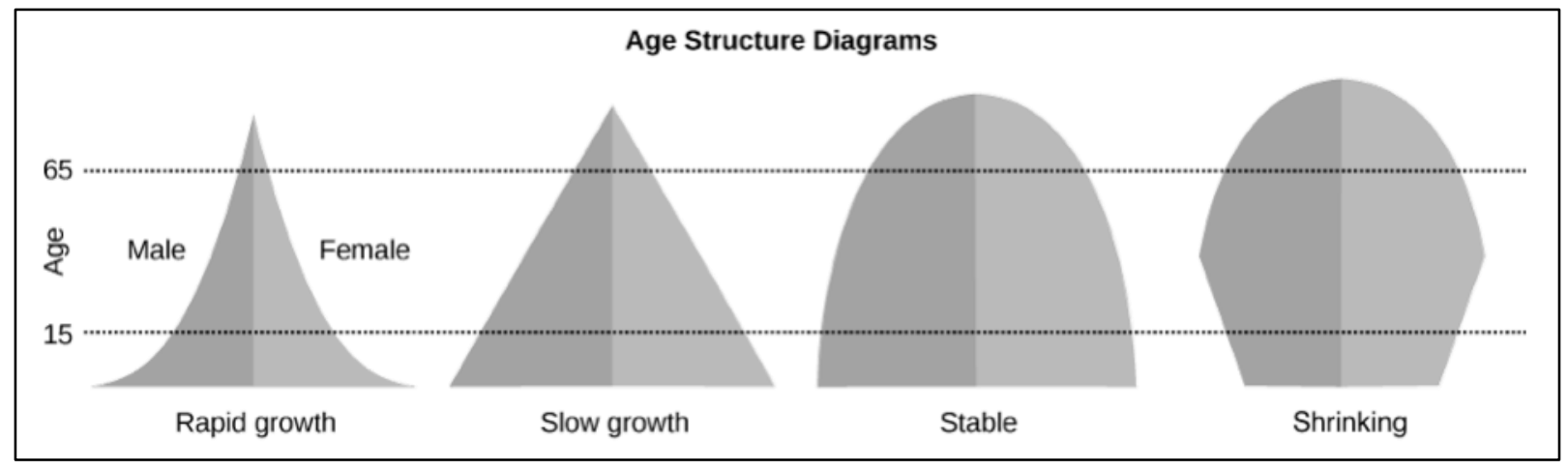

Source: Avissar et al., 2013, p. 1337

The age pyramids are due to the movement of the labor force suitable tool for analyzing generational groups (easy resolution and work with data about generational groups). A certain disadvantage may be the fact that population migration is not included in the pyramid, which in some economies may in part distort the corresponding data.

\section{Generations}

The term of generation is closely related to the concept of a generation group. In defining this term it is necessary to mention that membership to a certain generation only on the basis of the same cultural-historical or economic conditions is very relative (Pavlik a Kalibova, 2005). This relativity is also based on the different generations distribution. There is a large number of different class divisions of individual groups in the literature (see below) (Benson and Brown, 2011; Lyons and Kuron, 2013; Deloitte, 2015; Robinson, 2017), which underlines the relativity of a certain group of individuals, especially those whose birth dates are between two generations. At the same time, in developing countries without sufficient population statistics, generations are defined alternatively. For example, India, which became a nation in 1948, has a generation of traditional (since 1948), non-traditional (since 1969) and Gen $Y$ (since 1981). On the contrary, Chinese generations have been deciding over decades. For the purpose of this paper, the world's most widely used distribution is used, but this does not always coincide with the yearly definition (Erickson, 2009a; Erickson, 2009b).

The oldest generation on the labor market is the Baby Boomers generation, which includes individuals born in the years 1946 to 1964 . The majority of domestic and foreign literature coincide with this definition (Hansen and Leuty; 2011; Kaifi et al., 2012; Lyons and Kuron, 2013). However, there is no such consensus on the classification of the coming generation, the generation $\mathbf{X}$. Some authors and sources report the 1965 to 1985 ranges (Crow, 1997; Robinson, 2017; Stanicek, 2017), others only until 1979 (Kaifi et al., 2012), when generation X was replaced by Xennials by 1985. This division is more likely to occur in US sources. In both cases, the next generation is the generation $\mathbf{Y}$, which is sometimes called the Millennials generation (mainly English-written texts) or the Next Gen generation (Deloitte, 2015). This is the generation of children by Baby Boomers. Their yearly rankings are from 1986 to 1997, 
when some sources are again different and the marginal year is mentioned in 2004 (Benson and Brown, 2011). The last generation is the generation Z, sometimes referred to as the generation $M$ or the Internet generation. Their yearly range is the end of the previous generation to the present. Necessary to point out that there is the ambiguity of the upper limit. Some institutions and authors, for example Robinson (2017), refer to the ending of the $Z$ generation in 2013, and it should be replaced by a generation with a still unsettled notion (starts to emerge eg. the term Alpha). This paper structures the generations (Robinson (2017), Stanicek (2017) etc.) as follows:

- Generation Baby Boomers: 1946-1964

- Generation X: 1965-1985

- Generation Y (Millennials): 1986-1997

- Generation Z: 1998-present.

\section{Generation Groups in the Czech Republic}

At present, four generation groups (Baby Boomers and $\mathrm{X}, \mathrm{Y}, \mathrm{Z}$ ) are present on the Czech labor market. The characteristics of these generations are made, especially in terms of their attitudes, opinions or values. It is also necessary to add that not all generational features can be generalized globally. Especially among older generations who experienced for example the Communist regime, values and attitudes are markedly different from other western states. On the contrary, the younger generations that have grown up in a globalized world are wiping out these differences (Stewart et al., 2017).

It is also worth mentioning the different development of the values of the individual generations in the global comparison. The main lines of the development can be seen from west to east. More precisely, many attitudes and aspects that are recorded in a given generation are often reflected in the other less developed countries in the next generation or generations (Hansen and Leuty, 2011).

Most of the following characteristics generations below are based on domestic conditions and data (except Generation Z, see below) and capture general trends. There are many individuals who are the part of a given generation and still do not hold on to that value. Therefore, these analyzes need to be taken to capture general trends rather than specific situations and individuals.

\section{Generation Baby Boomers}

This is the oldest generation on the labor market in CZE, which was influenced mainly by political development, more precisely relaxed atmosphere of the Prague Spring and the subsequent Normalization. Because of their older age, they have undergone many changes in their careers, and can thus somehow compare and critically evaluate. The key word is therefore experience. Their core values include job security, loyalty and long-term employment (Lyons and Kuron, 2013). At the same time, it is the generation that directly claims that job priorities are superior to personal life, which implies that representatives do not lay specific requirements on the balance between work and personal life. That is the difference between generation groups across 
different states. For example, Kaifi et al. (2012) have come to the conclusion that American representatives of this generation place emphasis on the balance between personal and professional life, even though this phenomenon is typical for generations of the following generation $X$ in Czech conditions (Novak, 2018)

Another specific feature of this generation is that money (wage, salary, etc.) is a means of gaining respect and position. They spend the most on family - for their parents and children. With their superiors, they do not have an increased interest in cooperating, they rather welcome from their supervisors a clear message of their satisfaction and performance (Moore, 2013). 17\% of representatives of the generation Baby Boomers have a university degree in the CZE. Regarding the use of information and communication technologies, despite the fact that $74 \%$ own the Internet, representatives of this generation prefer phone contact (Forbes, 2017).

\section{Generation X}

This generation is referred to as the generation of Husak's children, experienced both by socialism and the so-called wild nineties (Forbes, 2017). Unlike their parents, they pay much more attention to the balance of their personal and working life, but also perceive the monetary certainty they consider to be their own housing. Even though their loyalty to the employer is gradually decreasing, they are still willing to get up early or work overtime. At the same time, the representatives of the generation do not place special requirements on the place of work (Moore, 2013).

Almost every representative of this generation already has access to the Internet, which is also used as a means of communication and entertainment (Stewart et al., 2017). Generation $X$ is also characterized by the willingness to develop its skills and to face different professional challenges (Stollen and Wolf, 2017). These challenges include, among other things, the instability of work, more precisely the case of change of position or degradation to a lower post (Amanet, 2018).

\section{Generation Y - Millennials}

Millennials are representatives of the first globalized generation for whom the typical word is online (Stewart et al., 2017). Among other things, they are also impatient and very demanding (Moore, 2013). Because of their education, the highest in the Czech labor market - college graduated every third - it is possible to expect certain problems with their determination and personal conviction (Lyons and Kuron, 2014). The Internet is a matter of course, even $99.9 \%$ of individuals of this generation own a mobile phone (Forbes, 2017). They use it as a tool of communication, but not by means of messages or calls, but above all through various applications and social networks (Novak, 2018). Work-life-balance is the mantra of this generation (Myers and Sadaghiani, 2010).

An interesting fact that gives this generation a certain kind of respect and influence is the size of this generation relative to the yearly composition. Both the passing generations (Baby Boomers and $X$ ) and the next generation $(Z)$ have a yearly range of about 20 years. However, the generation $Y$ has in many sources, and also in this 
paper, the range of years only 10 years (Robinson, 2017). Despite this fact, the Millennials (as one of four generations) represent approximately $20 \%$ of economically active representatives of generational groups in CZE (MLSA, 2017).

\section{Generation Z}

It is the youngest generation on the Czech labor market, which does not significantly differ from the $\mathrm{Y}$ generation in its values. Like them, it is still online and it is also very popular with information and telecommunication technologies. According to a study by Deloitte (2015), over $70 \%$ of generation representatives believe business should also have a positive impact on the social environment (global data). Like previous generations $Y$, they have a great personal conviction and determination, such as a possible rapid career growth. The most important factor for representatives of this generation $(31 \%)$ is to find a suitable job (Adecco, 2018), which means that they are able to rotate many jobs while being financially and materially supported by their parents (Forbes, 2017). Parents express their support in this way, based on their ambitions. Unlike older generations (Baby Boomers or X), they do not pay a significant weight on wages, but they expect the level of wage will satisfy all their wishes (travel, personal life). Given the many possibilities, this generation is characterized by the ability of multitasking (Hammill, 2005). It is also the first generation that has not yet been aware of the impact of the global economic crisis in its professional life, which often results in lowering the standard of living, redundancy or wage cuts.

As has already been mentioned above, it is not possible to rely on a large number of studies and studies on the characteristics of the generation $Z$ since the first representatives of this generation have just entered their professional life. Moreover, it is more about persons with basic and secondary education, which slightly distorts the results of possible research. Above all, when one third of the previous generation $(Y)$ (Forbes, 2017) holds a university diploma, and when this trend is expected also in this generation.

\section{Methodology}

The aim of the analysis is to evaluate the current status and future trend of labor force development in the form of generational groups in the Czech Republic with an emphasis on the demographic factor and the labor market.

In order to achieve the defined aim, the method of primary analysis of secondary data is used in this paper. This method mainly uses already published studies based on original research, which compares or complements the statistical data, which are published by the Czech Statistical Office ("CZSO") and the Ministry of Labor and Social Affairs of the Czech Republic. The essence is the comparison of statistical data, which is modified or supplemented by annual comparisons of individual generations. 


\section{Analysis}

This part of the paper describes employment and unemployment in the Czech Republic, always with respect to individual generations. Further, the current and future demographic development is also analyzed in the chapter, again with regard to generational groups. These analyzes are subjected to a common comparison and the results of the analysis that are the basis for the formulation of recommendations for business practice in the following section.

\section{Employment and Generation Groups in the Czech Republic}

According to the data of the MLSA (2017), the number of employed in all sectors of the Czech economy in the first half of 2017 reached the figure of 5.2 million persons, the highest value since the establishment of the independent Czech Republic. The year-on-year increase was $1.5 \%$.

In terms of age distribution in the labor market, the situation is the following. If we focus on specific age structures, Table 1 below shows employment rates by age group. Even though the age groups do not correspond directly to the age distribution of the individual generational groups, it is possible to use the information presented below with regard to the relativity belonging to individual groups of ages (see chapter Generations).

Table (1): Age Structure of Employed Persons in CZE (\%)

\begin{tabular}{|c|c|c|}
\hline $\begin{array}{c}\text { Age } \\
\text { groups }\end{array}$ & $\begin{array}{c}\text { Number of employed } \\
\text { (in thousands) }\end{array}$ & $\begin{array}{c}\text { Share in total } \\
\text { employment (\%) }\end{array}$ \\
\hline $15-24$ & 289.3 & 6 \\
\hline $25-39$ & 1830.2 & 35 \\
\hline $40-54$ & 2123.1 & 41 \\
\hline $55-64$ & 818.4 & 16 \\
\hline $65+$ & 122.2 & 2 \\
\hline Total & $\mathbf{5 1 8 3 . 2}$ & $\mathbf{1 0 0}$ \\
\hline
\end{tabular}

Source: own processing, 2018

From the data presented in the table above, it is clear that the largest share of employment, namely $41 \%$, has an age structure of $40-54$ years, which corresponds to the $X$ generation. The second largest share represents 35\% of the age group of 25-39 years, representing in part the $X$ generation and partly the $Y$ generation. The age groups $55-64$ and $65+(18 \%$ in total) are represented by the generation Baby Boomers and the 15-24 age group, which has a 6\% share, represent for the most part the youngest generation $Z$.

From the analyzed is therefore apparent that the generation that gradually leaving the labor market is the generation Baby Boomers, now represented by $18 \%$ of all employees. Generations, which on the contrary is entering the labor market is generation Z, which currently has just over 200,000 employed people in its group (about $5 \%$ ). The largest share among employees is occupied by generation $\mathbf{X}$, which 
covers roughly half of all. The remaining less than $30 \%$ comes to the so-called Millennials (generation $Y$ ).

\section{Unemployment and Generation Groups in the Czech Republic}

The labor market, specifically the unemployment rate, presents data on the Figure (1). There is the trend of decline, which started in 2014 and by the year 2017, the share of unemployed persons decreased by about 5 percentage points.

Figure (1): Development of Unemployment Rate in CZE (\%)

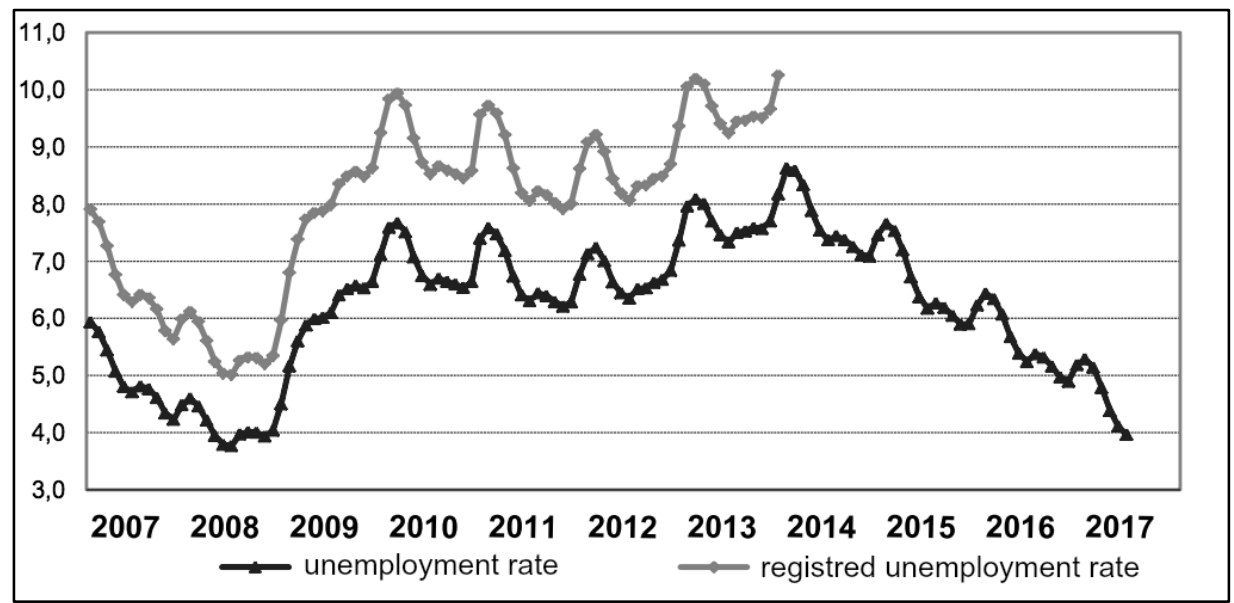

Source: own processing according to MLSA, 2017

The relation of unemployment with respect to the individual age groups of the population in their absolute terms is shown in Table 2.

Table (2): Age Structure of Unmployed Persons in CZE (\%)

\begin{tabular}{|c|c|c|}
\hline Age groups & $\begin{array}{c}\text { Number of } \\
\text { unemployed } \\
\text { (in thousands) }\end{array}$ & $\begin{array}{c}\text { Share in total } \\
\text { unemployment } \\
\text { (\%) }\end{array}$ \\
\hline $15-19$ & 8.7 & 3 \\
\hline $20-24$ & 24.7 & 8 \\
\hline $25-29$ & 29.6 & 10 \\
\hline $30-34$ & 29.2 & 10 \\
\hline $35-39$ & 32.8 & 11 \\
\hline $40-44$ & 35.2 & 12 \\
\hline $45-49$ & 30.8 & 10 \\
\hline $50-54$ & 35.9 & 12 \\
\hline $55-59$ & 43.8 & 15 \\
\hline $60-64$ & 25.5 & 9 \\
\hline $65+$ & 1.5 & 1 \\
\hline Total & $\mathbf{2 9 7 . 7}$ & 100 \\
\hline
\end{tabular}

Source: own processing, 2018

Due to the availability of more accurate age data, individual shares can be assigned exactly to the individual generational groups. Generation Z (15-19) represents a 3\% 
share of unemployment, generation $Y(20-29) 18 \%$, generation $X(30-49) 42 \%$ and the oldest generation Baby Boomers (50-65+) 37\%.

When comparing the age structure, or the structure of the generational groups, that are represented among the employed and unemployed in the Czech Republic, it can be concluded that the percentage of the rising generation $Z$ and entrenched Generation $X$ is more or less identical. Different values, on the other hand, are based on the Millennials $(\mathrm{Y})$ generation, with a share of $30 \%$, the unemployed only $18 \%$. On the contrary, it is the oldest generation of Baby Boomers, with a share of $18 \%$, but the unemployed represent $33 \%$. The values of the generations are therefore almost inverse. The explanation is of course the greater attractiveness of the younger generation $(\mathrm{Y})$ compared to people in pre-retirement age.

\section{Demographic Development in the Czech Republic}

The following subchapter analyzes the current and future trend of population development in CZE. A suitable tool for this analysis is the age pyramid, which contains data about the Czech population at the beginning of 2017.

\section{Figure (2): Age Pyramid of CZE (2017)}

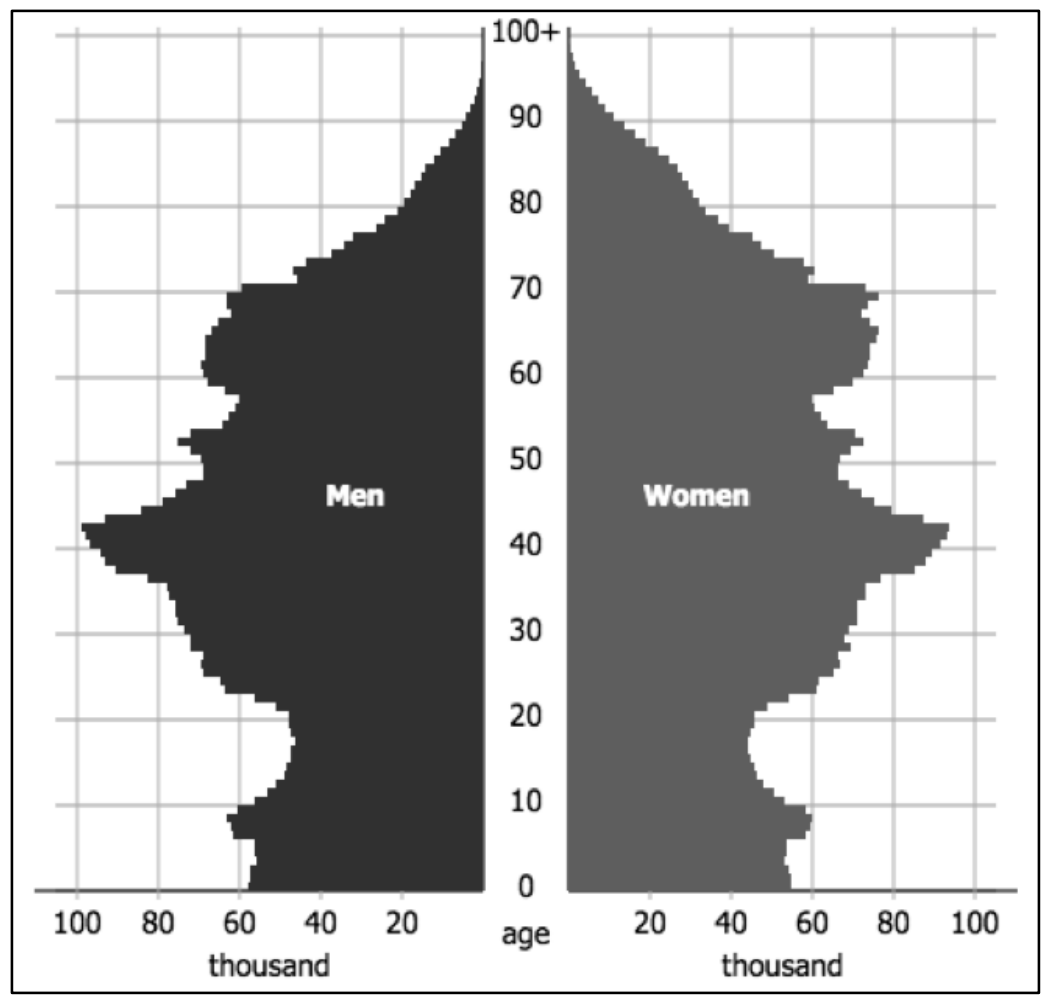

Source: CZSO, 2017

The data from the Figure (2) show that the pyramid represents a regressive type, but the proportion of retired citizens does not currently predominate. If the data on the age structure is used again, the following representations of individual generations are achieved in the total population:

- Generation Baby Boomers: 2.5 million $=24 \%$

- Generation X: 3.3 million $=31 \%$ 
- Generation Y: 1.4 million $=13 \%$

- Generation Z: 2.2 million = 21\% (own processing according to CZSO, 2017).

It is necessary to mention the fact that the demographic data are not directly comparable with the data on the representation of individual generations in the form of labor force. This can be demonstrated, for example, by the representation of Generation Z, where we work in sociodemographic analysis with individuals from 0 to 20 years of age, although the analysis of the representation of individual generations as a workforce is based only on individuals aged 15 years. However, sociodemographic data can be appropriately used to estimate the future representation of individual generations and the resulting impact on the business sphere.

When comparing the population development and labor market developments, it is possible, according to the MLSA (2017), concluded that the development of employment in terms of its age structure did not differ significantly from the development of the age structure of the Czech population itself. The opposite trend was recorded only in the 55-64 age group, when the population dropped by 30.4 thousand, the number of employed increased by 34.9 thousand. This development was particularly influenced by people aged 60-64 years, whose growth in employment is mainly related to longer stays in employment due to the increasing retirement age. This fact largely restricts the negative impact of the limitation of the paper in the form of comparison of demographic data and population development data.

For comparison with the labor market it is also important to estimate future trends that suggest the future composition of the workforce in the context of generational groups. It can then derive the necessary business processes to ensure sufficient workforce and mutual understanding. Unlike the above-mentioned sociodemographic analysis of the representation of individual generations in the total population, this estimate of the future trend is based only on persons between the ages of 15-64, which corresponds directly to labor statistics in CZE.

The following moves will occur in CZE and in the labor market in the next $\mathbf{5}$ years. Approximately half a million representatives of the generation $Z$ (older than 15 years) will enter the labor market, while about 700 thousand representatives of the Baby Boomers generation will leave the labor market. It is necessary to consider that at the age of 15 , many representatives (especially in developed economies) are still studying and are therefore not counted in the workforce and vice versa, a certain part of the population older than 64 may not always respect the retirement age and may be economically active. For generations $Y$ and $X$ there will be no change in percentages without external causes.

For the 10-year forecast, the situation will be the following. The labor market is already about 1 million new representatives Generation Z (a total of 1.6 million representatives from the generation older than 15 years), while the retirement age (65 years) reaches almost 1.5 million representatives of the Baby Boomers, who are also in the 10-year horizon will leave almost the entire labor market (the representatives of the generation will be $4 \%$ of the labor force). As far as the $\mathrm{Y}$ generation is concerned, 
its current position in the labor market will be supplemented by current learners. A large part of them will be mainly university graduates (those with completion of secondary education in the labor market already are). The oldest representatives of the $\mathrm{X}$ generation (10-year forecast) will begin to reach pre-retirement age and at the same time also higher and more competent job positions (CZSO, 2017). Their relative representation as well as that of the 5-year forecast is unchanged.

Table (3) below shows the percentage estimate of the share of individual generations in individuals aged 15-64 years (economically active population). However, it is not an accurate estimate of the relative share of generation representatives as a workforce. It is based only on demographic data without taking into account migration. Despite these constraints, it is possible to predict the general trend among generations on the basis of these data and to characterize the power of their impact on enterprises, and thus the labor market as a whole.

\section{Table (3): Representation of the Generation Aged 15-64 in CZE (\%)}

\begin{tabular}{|l|c|c|c|}
\hline & present & $\begin{array}{c}5 \text {-year } \\
\text { estimate }\end{array}$ & $\begin{array}{c}\text { 10-year } \\
\text { estimate }\end{array}$ \\
\hline Generation Z & 8 & 16 & 25 \\
\hline Generation Y & 21 & 21 & 21 \\
\hline Generation X & 48 & 50 & 50 \\
\hline Generation Baby Boomers & 23 & 13 & 4 \\
\hline
\end{tabular}

Source: own processing, 2018

\section{Evaluation and Discussion}

According to the expected trend of development, relatively important changes can be expected on the labor market based on population development as well as changes in the representation of individual generational groups. As mentioned above, during the next 5 to 10 years, the Baby Boomers generation will gradually exit the labor market and will be replaced at least in part by the generation Z. However, an important element is the "at least in part". Already from the age pyramid and from the description of population development, one can read the oncoming problem, which is represented by a lack of labor force. In the near future will gradually leave the labor market more people than it will enter (here we do not take into account migration). One of the possible threats that correlates with this problem is the occupation of higher jobs, which are represented primarily by more experienced and therefore older individuals. Given the ambitions of individual generations (especially $Y$ and $Z$ ), companies will need to deal with this situation. In addition to the above-mentioned young and predatory generations, there is still a generation $\mathrm{X}$ on the labor market, which is waiting for its entire career on releasing a high-ranking position.

Despite the threat mentioned, the diversity of generations, which is represented by a large number of different experiences, views and skills, is seen as one of the advantages of the current composition of the labor market. Considering the trend seen in the generations $Y$ and $Z$, there will be a gradual wiping out of larger generational 
differences, and the generation on the labor market will be rather similar (Myers and Sadaghiani, 2010). Similarity, of course, is not only a shadowy side. The concrete positive example may be, for example, affection for a teamwork or access to information and telecommunication technologies.

Another threat that companies and the whole economy have to deal with is the gradual departure of the Baby Boomers from the labor market. There is already a large share of the generations' representatives in total unemployment. It is also evident from the statistics that the increase in unemployment in this generation grows annually since 2015 by 2 percentage points. The main reasons are by Bilkova (2018), for example, a certain stereotype as by businesses and by the unemployed. There are fears that older individuals will not be able to work with modern technologies or that they will not be tempted to work by their age. The described solves programs of labor offices that focus on the support and retraining of people over 50 years of age.The problem of unemployment among baby boomers but also solves the economy as such, more accurately its development. At a time of growth, when there is excessive shortage of workers, enterprises are forced to accept and to employ representatives of that generation who are offered positions with low physical demands.

Due to the fact that both the present and the near future will have 4 or 3 generation generations with different characteristics in the labor market, it will also be necessary to adapt certain processes and approaches in companies.

The first factor that will be influenced by the different generations is the system of evaluation (remuneration, motivation). Although financial remuneration is still the most important factor (Adecco, 2018), especially among the younger generation, financial resources play a fundamental role when deciding on future jobs or staying in it. On the other hand, the generations Baby Boomers and X, whose characteristics show that work is primarily a source of financial resources, must be rewarded in this way. The question is how to apply a system of evaluation of two representatives of different generations on the same post so that both representatives are satisfied and at the same time that this difference does not incite some contradictions in the corporate culture (Pollak, 2017). The difference will be seen also among non-financial benefits. Especially for younger generations these benefits are often very desirable. Nevertheless, according to the graph data, it is clear that the Czech Republic is significantly below the EU average in the use of shorter working hours, even though it is one of the so-called demands of younger generations (Adecco, 2018). 
Figure (3): Use of Shorter Working Hours in the Czech Republic and the EU 2012-2017 (\%)

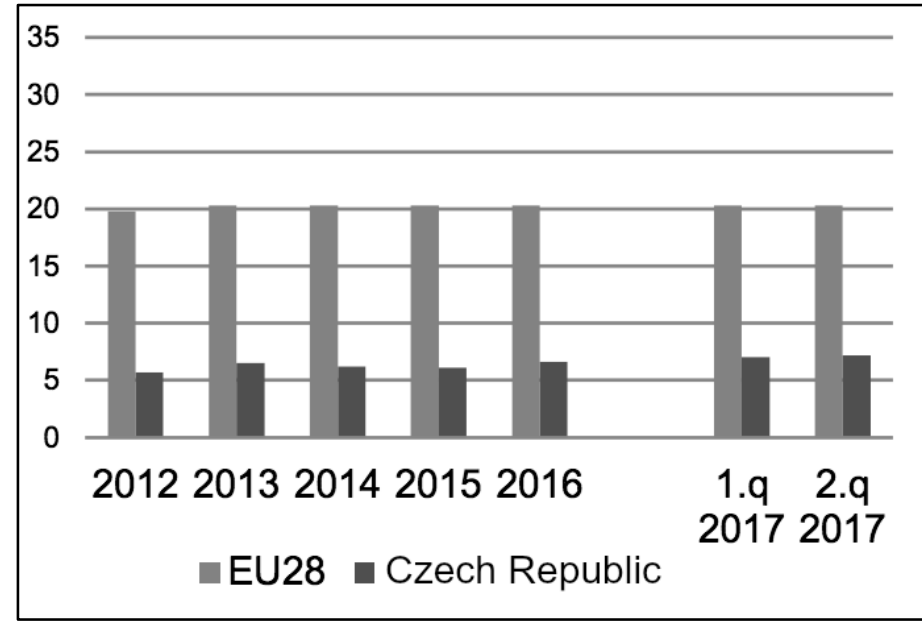

Source: own processing according to MLSA, 2017

As a further factor we can mark the process of communication in an enterprise. In most enterprices, one or few types of communication (Mukherji and Arora, 2017) can be encountered, which may not, especially in modern times, satisfy all generations. The result of the research is that Baby Boomers or $\mathrm{X}$ generation prefer mainly word communication, e-mail communication, and telephone. On the other hand, representatives of the $\mathrm{Y}$ and $\mathrm{Z}$ generations are communicating through social networks or other computer and mobile communication channels because of their technological skills and experience. Businesses should therefore choose different channels to communicate with different generations. When demanding unified communications, quality training for a certain type of communication channel is emerging as a solution that will be understood and used by all employees. Communication itself is also one of the tools to overcome any generational differences and mutual cooperation and understanding.

However, the mutual co-operation can also be ensured through appropriate mentoring. Its importance is further supported by the gradual change of generations both in the labor market (Baby Boomers vs. Generation Z) and in the jobs themselves (all generations). Based on the above-mentioned characteristics of the Baby Boomers generation, the representatives of this group are not used to working with their superiors in their professional lives. However, the representatives of this generation themselves become supervisors. As a generation who, due to its career termination, will be forced to pass on their work position to the next generation, it is necessary for companies to ensure so-called smooth transition and mutual mentoring. This issue also relates to the replacement of higher positions mentioned at the beginning of this chapter.

With the diversity of many generations in the workplace, companies can not continue to follow traditional established management and management rules. Organizations can achieve real strategic benefits by developing and appropriately managing 
intergenerational diversity to create a flexible working environment that evaluates and keeps people productive regardless of generational rankings.

\section{Conclusion}

In the paper the author defined theoretically and, using the meta-analysis, analyzed the data related to issues of generations. This paper also describes and practically analyzes statistical data from the Czech labor market and the demographic data. The outputs were compared to each other in the Evaluation and Discussion chapter, where the recommendations for business practice are presented.

As mentioned, it will be important to further analyze opinion and value changes for the generation $Z$ characteristic. These aspects are often reflected in longitudinal studies, where it will be possible to monitor the response to the first change in career life or to the economic crisis. For this purpose, it will be appropriate to compare the obtained data with the trends that were given in previous generations.

\section{Limitations}

Among the limitations of this study may include abstracting from possible migration of the population. Both immigration and emigration can, due to the nature of the economy, affect the number of representatives of each generation. Additional restrictions can be seen in the description of generational groups, especially among Generation Z. It is the youngest generation group, which is now entering the labor market and currently is not processed sufficient number of studies, specifically in Czech conditions. However, it is a generation that takes a global nature and it is expected that its characteristics, attitudes and opinions will not significantly differ in the global field of advanced economies.

The last limitation is in the form of the estimate of the trend of the future development of generational groups in the labor market. The author of the paper works with statistical demographic data, which means that the population of the generation does not directly correspond to the workforce of a given generation (heavily ill, rentiers, etc.). Nevertheless, the relative expression between generations has reduced the impact of this difference to a certain extent.

\section{References}

Adecco. (2018). Generation Z vs. Millennials in the Workplace / Adecco. [online] Available at: https://www.adeccousa.com/employers/resources/generation-z-vs-millennials-infographic/ [Accessed 27 Mar. 2018].

Amanet. (2018). Leading the Four Generations at Work. [online] Available at: http://www.amanet.org/training/articles/leading-the-four-generations-at-work.aspx [Accessed 3 Apr. 2018].

Ardielli, E. (2016). Development and Administration of Border Areas of the Czech Republic and Poland. Ostrava: VŠB - Technical University of Ostrava.

Avissar, Y., Choi, J., DeSaix, J., Jurukovski, V. and Rye, C. (2013). Biology. Houston: Rice University, p.1337. 
Benson, J. and Brown, M. (2011). Generations at work: are there differences and do they matter?. The International Journal of Human Resource Management, 22(9), pp.1843-1865.

Bilkova, M. (2018). Nezaměstnaní nad 50 let.

Cabla, A. and Mala, I. (2017). Modelling of Unemployment Duration in the Czech Republic. Prague Economic Papers, 26(4), pp.438-449.

Crow, K. (1997). Generation X and the Church of the Nazarene. [online] Available at: http://citeseerx.ist.psu.edu/viewdoc/download?doi=10.1.1.580.6765\&rep=rep1\&type=pdf [Accessed 10 Apr. 2018].

CZSO (2017). Čsú - Věková struktura. [online] Czso.cz. Available at: https://www.czso.cz/staticke/animgraf/cz/ [Accessed 23 Apr. 2018].

CZSO (2018). Výstupní objekt VDB. [online] Vdb.czso.cz. Available at: https://vdb.czso.cz/vdbvo2/faces/cs/index.jsf?page=vystup-

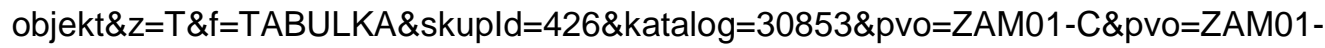
C\&u=v413_VUZEMI_97_19 [Accessed 28 Apr. 2018].

Deloitte (2015). Mind the gaps. The 2015 Deloitte Millennials survey. Touche Tohmatsu.

Dufek, P. (2018). Rekordní nabídka volných míst. [online] Patria.cz. Available at: https://www.patria.cz/zpravodajstvi/3773471/flash-nezamestnanost-v-cr-v-unoru-klesla-na-37mist-opet-pribylo.html [Accessed 9 Apr. 2018].

Erickson, T. (2009a). Generational Differences Between India and the U.S.. [online] Harvard Business Review. Available at: https://hbr.org/2009/02/global-generations-focus-on-in [Accessed 5 Apr. 2018].

Erickson, T. (2009b). Generations in China. [online] Harvard Business Review. Available at: https://hbr.org/2009/03/generations-in-china [Accessed 5 Apr. 2018].

Forbes (2017). Boj o generace.... [online] Boj o generace... Available at: http://generace.forbes.cz/ [Accessed 1 Apr. 2018].

Hammill, G. (2005). Mixing and Managing Four Generations of Employees. [online] FDU Magazine online. Available at: https://www.fdu.edu/newspubs/magazine/05ws/generations.htm [Accessed 28 Mar. 2018].

Hansen, J. and Leuty, M. (2011). Work Values Across Generations. Journal of Career Assessment, 20(1), pp.34-52.

Hedvičáková, M. and Svobodová, L. (2017). Trh práce České republiky v kontextu průmyslu 4.0. XX. mezinárodní kolokvium o regionálních vědách. Sborník př́íspěvkủ..

Jandourek, J. (2007). Sociologický slovník. Praha: Portál, p.94.

Kaifi, B., Nafei, W., Khanfar, N. and Kaifi, M. (2012). A Multi-Generational Workforce: Managing and Understanding Millennials. International Journal of Business and Management, 7(24).

Koschin, F. (2005). Demografie poprvé. Praha: Oeconomica. 
Lyons, S. and Kuron, L. (2013). Generational differences in the workplace: A review of the evidence and directions for future research. Journal of Organizational Behavior, 35(S1), pp.S139-S157.

Mach, M. (2001). Makroekonomie II. Slaný: Melandrium.

Mannheim, K. and Wolff, K. (1993). From Karl Mannheim. London: Transaction Publishers.

Ministerstvo práce a sociálních věcí (MLSA) (2017). Analýza vývoje zaměstnanosti a nezaměstnanosti $v$ 1. pololetí 2017. MPSV-2017/220436-992. [online] Praha: MLSA. Available at: https://portal.mpsv.cz/sz/politikazamest/trh_prace/rok2017p1/anal2017p1.pdf [Accessed 1 May 2018].

Moore, G. (2013). Baby Boomers, Generation ' $X$ ' and Generation ' $Y$ ' in the Workplace. [online] Resource 1. Available at: https://www.resource1.com/baby-boomers-generation-x-andgeneration-y-in-the-workplace-a-melting-pot-of-expertise/ [Accessed 26 Apr. 2018].

Mukherji, S. and Arora, N. (2017). Digital Communication: Easing Operational Outcomes in the Workplace. Procedia Computer Science, 122, pp.1084-1091.

Myers, K. and Sadaghiani, K. (2010). Millennials in the Workplace: A Communication Perspective on Millennials' Organizational Relationships and Performance. Journal of Business and Psychology, 25(2), pp.225-238.

Novak, J. (2018). The Six Living Generations In America. [online] Marketingteacher.com. Available at: http://www.marketingteacher.com/the-six-living-generations-in-america/ [Accessed 11 Apr. 2018].

Pavlík, Z. and Kalibová, K. (2005). Mnohojazyčný demografický slovník. Praha: Česká demografická společnost.

Pollak, L. (2017). What are the Different Generations in the Workplace? Your Definitive Guide / Lindsey Pollak. [online] Lindsey Pollak. Available at: https://www.lindseypollak.com/different-generationsworkplace-definitive-guide/ [Accessed 1 Apr. 2018].

Preston, S., Guillot, M. and Heuveline, P. (2009). Demography. Oxford [u.a.]: Blackwell.

Robinson, M. (2017). The Generations - Which Generation are You?. [online] Careerplanner.com. Available at: https://www.careerplanner.com/Career-Articles/Generations.cfm [Accessed 29 Mar. 2018].

Stanicek, J. (2017). GENERATION WHY?! - EDTECH KISK - Medium. [online] Medium. Available at: https://medium.com/edtech-kisk/generation-why-2fa363da25e0 [Accessed 2 Mar. 2018].

Stewart, J., Oliver, E., Cravens, K. and Oishi, S. (2017). Managing millennials: Embracing generational differences. Business Horizons, 60(1), pp.45-54.

Stollen, M. and Wolf, G. (2017). Between Generation X and the Millennials: There is a term for people born in the early 80s. [online] The Independent. Available at: https://www.independent.co.uk/lifestyle/how-old-are-millennials-when-born-generation-x-80s-called-child-of-nineties-a8043806.html [Accessed 9 Mar. 2018] 